\title{
Karlovy Vary 2012
}

\author{
By Gönül Dönmez-Colin
}

Fall 2012 Issue of KINEMA

\section{$47^{\text {th }}$ KARLOVY VARY FILM FESTIVAL}

Over 200 films, including 34 shorts and 56 documentaries, with 23 world premieres and more than 120,000 tickets sold. Karlovy Vary International Film Festival celebrated its $47^{\text {th }}$ year with triumph this summer despite budget cuts that have also been menacing many other film festivals. The Grand Jury, headed by Richard Peña, programme director of New York Film Festival, and including Montreal's well-known actor François Papineau, judged a dozen films over eight days (June 29 - July 7, 2012).

In the Official Competition, Pele akher (The Last Step) by Ali Mosaffa from Iran, focused on a somewhat confused young wife-widow played by Leila Hatami, well-known for her role as an irritable housewife in Asghar Farhadi's Oscar winner, A Separation. The Last Step however lacked the well-written script of $A$ Separation and also suffered from Hatami's being cast in a similar role as in her earlier film, The feature, a loose adaptation inspired by Tolstoy's novella The Death of Ivan Ilyich (1886) and James Joyce's story The Dead (1914) was more like a pastiche of several Iranian films that preceded it. French Canadian Rafaël Ouellet's Camion about a truck-driver whose life changes drastically following a traffic accident that leaves an unknown woman dead captivated the audience with its remarkable cinematography and sound narrative that succeeded in avoiding melodrama despite its subject matter.

Deine Schönheit ist nichts wert (Your Beauty is Worth Nothing) by Hüseyin Tabak, an Austrian entry whose 'filmic' identity became controversial in Turkey after having won several awards, including the best Turkish film at Antalya Golden Orange Film Festival's national competition, focused on a twelve-year old boy from Turkey and his alienation as an immigrant in Vienna. Mer eller mindre mann (The Almost Man) by Martin Lund (Norway) was a psychological study of a grown-up man soon to be a father who would not give up his adolescent tendencies. Henrik Rafaelsen's performance as the insecure protagonist was remarkable. The Czech entry, Polski Film, by Marek Najbrt, with well-known Czech actors playing themselves was a reflection about the thin line between reality and fiction, fame and the art of filmmaking. From Greece, a very original film by Ektoras Lygizos, To agori troi to fagito tou pouliou (Boy Eating the Bird's Food) was about preserving human dignity at times of crisis, told through the means of allegory.

In the Horizons section, Deep Blue Sea by Terence Davies is a story of black passion adapted from playwright Terence Rattigan's eponymous work, displaying influences of Douglas Sirk and Max Ophüls. It focused on a forty year old housewife comfortably married to a rich but rather dull gentleman in the early 1950s England, who falls madly in love with a rather irresponsible ex-RAF pilot and breaks free of all conventions. A typical melodrama? In the hands of the master, with leaps in time through reminiscences, the film carried the viewer to the end without signs of boredom despite the melodramatic tendencies of the subject. The one that got the most sympathy was the deserted husband (with a nagging aristocrat mother to boot) who never lost his dignity cherishing his loyalty higher than passion. The Angel's Share by Ken Loach carried the conventional story of delinquents and an adult male in charge of them carrying the burden of his own problems and who is searching his own catharsis. Reality by Matteo Garrone was a pure Italian comedy, realistic in its depiction of working class neighbourhoods, aspirations of the disadvantaged young, shaped by the celluloid lives on the television screen and the inevitable disappointments. A Fellini in the making? The overweight women, not unlike $8 \frac{1}{2}$ were in abundance. The opening scene depicting kitsch weddings, to be a princess for a day to escape the mundane life was marvellously choreographed.

Paolo and Vittorio Taviani's Golden Bear winner, Cesare deve morire (Caesar Must Die), a film that carves a niche in memory, was about Shakespeare, Julius Caesar and Brutus, but more than these, it was about humanity, the human side of all men, regardless of what they have done with their lives and what life has done to them. Wes Anderson's Moonrise Kingdom was a marvellous satire on small town middle-class life that would appeal to all ages. Newcomer Kara Hayward's acting stood on its own along with veterans like Bruce Willis, Bill Murray, Harvey Keitel and Frances McDormand. 
A restored version of Lawrence of Arabia (David Lean, 1962) gave some of the most enjoyable moments to the festival-goers just as last year's restored 1963 classic America America by Elia Kazan.

A tribute to one of the young talents of new Turkish cinema, Reha Erdem was a wonderfully curated program to familiarize the East European film-lovers with new trends in Turkey. Included were six feature films, from his debut, the black and white, somewhat experimental $A$ ay $(O h$, Moon, 1989) to his fantastical Kosmos (2010), including such gems as Be Vakit (Times and Winds, 2006) and my favourite Hayat Var (My Only Sunshine, 2008).

Two Oscar winning actresses were awarded this year with the Crystal Globe for lifetime achievement: Helen Mirren during the opening ceremony and Susan Sarandon at the closing ceremony. Sarandon also presented the film Jeff, Who Lives at Home (Duplass Brothers), a low key comedy about the attractive mother of two grown-up sons acting like kids.

The festival closed with the latest opus of Woody Allen, To Rome With Love, starring Penelope Cruz, once again as a prostitute.

Karlovy Vary plays along with the star mania and the starlet dreams. The Cannes of Eastern Europe, in Western Bohemia of the Czech Republic, it is on the confluence of the rivers Ohře and Teplá. The locale of Last Holiday (Wayne Wang, 2006) and James Bond's Casino Royale (Martin Campbell, 2006), the festival has a large audience, majority of which is young. Some arrive from neighbouring provinces, if not countries, with their sleeping bags to spend the nights in the parks. The music from the bars is deafening; beer is consumed in plenty, all of which adds to the tinsel-town atmosphere in a city reputed for its excellent spas. Do they all love cinema other weeks of the year as well, or is it the festival hype?

For the seriously minded festival-goer, obtaining tickets poses a major logistic problem. Skipping breakfast to lay hands on the coveted tickets, the press (or even the members of what is called 'non-statutory juries', i.e. FIPRESCI, Ecumenical, NETPAC, etc.) may return empty handed as the line in front of the ticket office is often filled with locals collecting tickets for themselves and their friends. Often you end up seeing what you never intended to rather than spending the precious hours with nothing better to do and luckily, once in a while, there are unexpected surprises. Variety in programming and the friendly atmosphere are the major attractions of this summer festival that make the long trip to the mountain resort of waters with curative powers worthwhile.

\section{References}

\section{AWARDS}

\section{Official Selection - Competition}

Grand Prix - Crystal Globe

The Almost Man (Mer eller mindre mann, Martin Lund, Norway, 2012)

Special Jury Prize

Piazza Fontana: The Italian Conspiracy (Romanzo di una strage, Marco Tullio Giordana, Italy, 2012)

Best Director Award

Rafaël Ouellet - Camion, Canada, 2012)

Best Actress Award

Leila Hatami - The Last Step (Peleh akhar by Ali Mosaffa, Iran, 2012)

Best Actor Award

Henrik Rafaelsen - The Almost Man (Mer eller mindre mann by Martin Lund, Norway, 2012)

Eryk Lubos - To Kill a Beaver (Zabić bobra by Jan Jakub Kolski, Poland, 2012)

Special Mention

Pavel Liška, Tomáš Matonoha, Marek Daniel, Josef Polášek - Polski film by Marek Najbrt, Czech RepublicPoland, 2012) 
Yannis Papadopoulos - Boy Eating the Bird's Food (To agori troi to fagito tou pouliou by Ektoras Lygizos Greece, 2012)

\section{East of the West - Films in Competition}

East of the West Award

House with a Turret (Dom s bashenkoy Eva Neymann Ukraine, 2011)

Special Mention

Vanishing Waves (Aurora, Kristina Buozyte \& Bruno Samper, Lithuania, France, Belgium, 2012)

\section{Documentary Films in Competition}

Best Documentary Film over 30 minutes

Sofia's Last Ambulance (Poslednata lineika na Sofia, Ilian Metev Bulgaria, Croatia, Germany, 2012)

Best Documentary Film under 30 minutes

A Story for the Modlins (Sergio Oksman Spain, 2012)

Special Mention

Private Universe (Soukromý vesmír, Helena Třeštíková, Czech Republic, 2012)

\section{Forum of Independents}

Independent Camera Award

Death of a Man in Balkans (Smrt čoveka na Balkanu, Miroslav Momčilović, Serbia, 2012)

Audience Award

Come As You Are (Hasta la vista, Geoffrey Eindhoven, Belgium, 2011)

Crystal Globe for Outstanding Artistic Contribution to World Cinema

Helen Mirren, United Kingdom and Susan Sarandon, USA

Festival President's Award

Josef Somr, Czech Republic

\section{Non-statutory Awards}

Award of International Film Critics (FIPRESCI)

The Last Step (Peleh Akhar), Ali Mosaffa Iran, 2012)

The Ecumenical Jury Award

Camion (Rafaël Ouellet Canada, 2012)

Special Mention

Hay Road (Estrada de Palha), Rodrigo Areias Portugal, Finland, 2011)

FEDEORA Award

Flower Buds (Poupata), Zdeněk Jiráský Czech Republic, 2011)

NETPAC Award

Tepenin Ardı (Beyond the Hill), Emin Alper Turkey, Greece, 2012)

Europa Cinemas Label Award

Piazza Fontana: The Italian Conspiracy (Romanzo di una strage, Marco Tullio Giordana, Italy, 2012)

\section{Author Information}

Gönül DÖNMEZ-COLIN is an independent researcher and writer whose publications include Women, Islam and Cinema, Cinemas of the Other: A personal Journey with Filmmakers from the Middle East and Central 
Asia, Cinema of North Africa and the Middle East (ed.); Turkish Cinema: Identity, Distance and Belonging (Reaktion Books), and Routledge Dictionary of Turkish Cinema (2014). 